\title{
Portuguese football coaches' migration: Patterns and networks in 2009-2013
}

\section{La migración de los entrenadores de fútbol portugueses: patrones y redes 2009-2013}

\author{
Mário Borges \\ School of Applied Sciences, London South Bank University, London, UK \\ borgesm@|sbu.ac.uk \\ https://orcid.org/0000-0001-9763-0292 \\ António Rosado \\ Faculty of Human Kinetics, University of Lisbon, Lisbon, Portugal \\ arosado@fmh.ulisboa.pt \\ https://orcid. org/0000-0003-2336-0853 \\ Rita de Oliveira \\ School of Applied Sciences, London South Bank University, London, UK \\ r.oliveira@lsbu.ac.uk \\ https://orcid. org/0000-0001-9454-0304 \\ Francisco Freitas \\ CES, Faculty of Economy, University of Coimbra, Coimbra, Portugal \\ ff@datadive.eu \\ https://orcid.org/0000-0002-1286-8750
}

Key words

- Football

- Coaches

- Networks

- Migration

- Globalization

\section{Palabras clave \\ - Fútbol \\ - Entrenadores \\ - Redes \\ - Migración \\ - Globalización}

\begin{abstract}
Sport migration is an important topic of global migration. It can capture migration patterns and the reliance on networks, which are specific to sports. This study seeks to identify the patterns and networks of Portuguese football coaches' migration between 2009 and 2013. This period is important because these were years of financial crisis with high rates of unemployment. We collected data about destination countries of migrant coaches. For coaches working abroad in 2013, we also collected data about their career path and networks including the assistant coaches and players with whom they had previously worked. The results showed that the destination of Portuguese football coaches involves both peripheral and central areas of football prestige. The pattern of migration suggests an overlap of economic, historical and cultural factors. On the other hand, the network relations of Portuguese football coaches were prominent in a zone of high prestige close to the native country, and in a zone with high financial incentives but lower football prestige. Taken together, these results highlight the career specificities of coaches who migrate to different countries including the role of networks on a football coaching career abroad.
\end{abstract}

\section{Resumen}

La migración deportiva es un tema importante dentro de la migración global. Puede ayudar a detectar patrones de migración y la dependencia de redes que son especificas de los deportes. Este estudio busca identificar los patrones y redes de migración de los entrenadores de fútbol portugueses entre 2009 y 2013. Este período es importante porque fueron años de crisis 
financiera con altas tasas de desempleo. Recopilamos datos sobre los países de destino de los entrenadores migrantes. Para los entrenadores que trabajaron en el extranjero en 2013, también recopilamos datos sobre su trayectoria profesional y sus redes, incluidos los entrenadores asistentes y los jugadores con los que habian trabajado anteriormente. Los resultados mostraron que el destino de los entrenadores de fútbol portugueses involucra áreas periféricas y centrales de prestigio futbolístico. El patrón de migración sugiere una superposición de factores económicos, históricos y culturales. Por otro lado, las relaciones en red de los entrenadores de fútbol portugueses fueron destacadas en una zona de alto prestigio cercana al país de origen, y en una zona con altos incentivos económicos pero menor prestigio futbolístico. En conjunto, estos resultados destacan las especificidades profesionales de los entrenadores que migran a diferentes países, incluido el papel de las redes en el desarrollo de una carrera profesional como entrenador de fútbol en el extranjero.

Sport migration is an important topic of global migration which can capture migration patterns and reliance on networks which are specific to sports. Research has examined sports migrations through different disciplines such as sociology, history, economy and geography (see Maguire, 1994). However, most studies focus only on players' migration and not on the patterns of coaches' migration. Some of the few studies about coaches have focused on the particularities of the English and Irish cases (see Carter, 2004; Taylor, 2010). Historically, English football coaches' migrated during the 1910s and 1930s to Europe and South America. Taylor (2010) analysed historical manuscripts and found that coaches relied on networks to gain information for their migrations to France, Netherlands and Spain. More recently, Carter (2004) showed that cultural patterns and language were relevant to coaches migrating to Ireland from Australian, New Zeeland, South Africa and South Asia countries (see for example the cricket coaches' migration from India and Pakistan in Carter, 2004). Also, the economic consequences of players' migration (but not coaches' migration) have been identified. According to Andreff (2011) host countries such as Portugal gain skilled football players from Brazil.This reduces the quality and development of Brazil's football with consequences to its economy. The author even suggests a tax (Coubertintax) on players' migration to reduce these negative effects. Looking at the particular case of Portuguese football players, Besson, Poli and Ravenel (2013) found that migration to foreign countries increased in 2011 due to the economic instability of the country (financial crisis). The rate of unemployment in Portugal in 2009 reached its highest level of the previous 30 years $(9.5 \%$; Lima, 2010) and by 2013 it was the second highest in Europe (16.5\%; Eurostat, 2014). No studies have examined the migration of Portuguese coaches after the start of the financial crisis in 2009. However, this period provides an excellent opportunity to investigate the migration patterns and networks of coaches under the pressure of economic and financial insecurity. Specifically, what countries hosted Portuguese coaches and what was the role of coaches' professional networks.

\section{Purpose and research questions}

In 2010 Taylor states that although "research on the migration of football players is gathering pace, we still know relatively little about the movement of football coaches, managers and trainers" (p. 139). It is important, however, to examine coaches' migration flows for three main reasons. First, it provides a framework of geographic locations and movements which will enhance our understanding of the dimensions influencing coaches' migration destinations. Based on previous studies we expect that coaches migrate primarily to the best leagues in Europe but also to countries with historical or colonial links (Borges et al., 2015). Second, it provides information about how coaches manage their careers in a situation of financial crisis. We expect that the economic instability in the country will have led to an increased volume of Portuguese coaches' migration (cf, Besson, Poli \& Ravenel, 2013). Third, it provides insight about the role of networks in Portuguese coaches' migration. A previous study suggested that Portuguese coaches may rely on informal networks to migrate (Borges et al., 2015) and therefore we expect to see large net- 
works supporting migrant coaches. Therefore in this study we seek to identify the patterns and networks of Portuguese football coaches' migration under the pressure of the financial crisis.

\section{The patterns of players' migration}

The patterns of sports migration of players have been examined according to geographical points based on donor and host countries. Geographic analyses have been made since the early 90s to understand players' migration (see the overview on sport geography by Bale \& Dejonghe, 2008). The pioneer studies of Bale (1989) and Bale and Maguire (1994) examined the patterns in rugby, cricket, ice hockey, baseball and football. The authors found that migration was mainly from Africa and Latin America to Europe and North America. Players' migration from South America and Africa to Europe was reinforced in studies about the flow of football players (Magee \& Sugden, 2002). Based on the world systems theory by Wallerstein (1974), Magee and Sugden (2002) proposed a division of the global football market in zones of economic prestige. At the core was Europe with the most prestige, then South America was semi-peripheral, Africa was peripheral, and without any prestige were Oceania, Asia and North and Central America. The authors argued that these zones of prestige justified the players' migration according to two main directions.

The first direction was players moving from the periphery to the core in order to work in the most prestigious leagues. For instance in 2008 Latin American and African players were found massively working in the top 30 European leagues (Poli \& Besson, 2011). The authors found that players from African French ex-colonies were more numerous in France and players from Latin American Portuguese and Spanish ex-colonies were more numerous in these two countries. Colonial links were also found in other studies, for example, Lafranchi and Taylor (2001) found that in France the immigration of Algerians, Moroccans and Senegalese players was massive during the 1930s. Some of these African immigrant players were naturalized French and made the national team. In Portugal, similar colonial relations were found during the 1950s and 1960s with Mozambican players, notably Matateu and Eusebio, who played in Portuguese clubs and also made the national team. Besides players moving from the periphery to the core, there was a second direction of migration from the core to the periphery. Players migrated from the core to disseminate football in peripheral zones where football was underdeveloped (Magee \& Sugden, 2002). For instance, Lafranchi and Taylor (2001) studied football players' migration in the $20^{\text {th }}$ century and showed the importance of English players in the diffusion of football in Europe and the consequent dissemination of football in the world by the European football players.

\section{The patterns of coaches' migration}

Coaches' migration has been related to the diffusion of football as a second wave of its globalization (Taylor, 2010). Taylor analyzed the pioneer migration of football coaches' during the 1910s and 1950s and found that English coaches moved abroad to countries were the cultural aspects such as language were similar. For instance, English coaches migrated to the United States of America, South Africa and Australia which are countries that share the same language and other cultural aspects disseminated by the English empire. Also, between Wars, English coaches were more present in The Netherlands, Germany, Switzerland, France and Spain. After the Second World War the largest number of coaches was found in Denmark, Norway, Sweden, USA, South Africa and Australia. These patterns of migration were important in the dissemination of football across Europe and the World. Interestingly, Smith (2014) points out that the pattern of contemporary migration are strongly reliant on the career contingencies of coaches, namely the fact that nowadays coaches work with a team for a relatively short duration (2.5 years in 1994 to 1.64 years in 2012). The author analyzed the career of high-level coaches and described three patterns of migration. First, coaches such as German Rehhagel or English Revie who established their careers in their native countries and subsequently migrated. Second, coaches such as English Hodgson who mainly worked abroad during their careers and later returned to their countries. Third, coaches such as Swedish Eriksson who mainly worked abroad (Smith, 2014).

A crucial aspect in the migration patterns of coaches and players is the recruitment process. Recent literature proposes that recruitment is primarily done through informal links often based on networks. Networks are the personal and professional relations that link coaches and players from the same native country in a foreign country. Research has found that head coaches prefer to hire assistant coaches and players from within their networks. For instance the migration of Canadian players to British ice hockey leagues was found to be based on the personal relations of Canadian coaches with other coaches and athletes (Elliott \& Maguire, 2011). Borges et al. (2015) 
also found that the recruitment of football and handball assistant coaches working in Africa and Europe was made by head coaches from the same country. In fact, coaches consider that recruitment through these informal relations are more effective than through formal networks (Agergaard \& Botelho, 2011; Borges et al., 2015).

\section{The Portuguese case of sport migration}

The pattern of players' migration has been described by the historical relations between the Portuguese empire and the African ex-colonies (Armstrong \& Giulianotti, 2004). For instance the authors describe how Portuguese missionary players introduced football to Mozambique, and how the Portuguese political situation during the 1950's and the 1980's contributed to the migration of skilled African players to the Portuguese football league. These migrations produced negative effects on the development of the Mozambican football which, devoid of their talented players, performed poorly in international competitions (Darby, 2007). Before the dictatorship fell in 1974, migration was curbed and Portuguese football players were not permitted to move abroad. This meant that there was no possibility for Portuguese players to move abroad. More recently, however, a socio-economic study classified Portugal as a hybrid country when it comes to the migration of football players because it is simultaneously a donor and a host country located in the semi-periphery of football prestige (Nolasco, 2010). After analyzing the football season of 2008-2009, he found that Portugal hosted South American players, mainly Brazilian (see also Poli 2008; Poli \& Besson, 2011) and donated footballers to Europe, mainly Cyprus and Spain (Nolasco, 2010). Further, Besson, Poli and Ravenel (2013) found that Portuguese football migration increased in 2011 not least because of its improved football prestige. They state that the Portuguese football players had gained prestige in the world football market because there are Portuguese players in the best football leagues such as Ronaldo and Nani in La Liga and the Premier League.

\section{Methods}

\section{Data collection}

To find out which Portuguese football coaches were working abroad on each calendar year, we collected secondary data from a number of sources between 2009 and 2013. Between 2009 and 2013 each coach was identified only once in a calendar year but may have changed countries throughout the year. We included head coaches who worked abroad in clubs competing in the first division of that foreign country as well as head coaches working in a foreign national team. For the coaches identified as working abroad in 2013 we gathered more detailed data about their entire career paths and networks since they first moved abroad. This type of collection method mirrors previous studies investigating players' migration (see Bale \& Maguire, 1994; Lanfranchi \& Taylor, 2001). We collected data by cross-referencing multiple sources, which included the official websites related to football such as FIFA, UEFA, AFC, CAF, CONCACAF, CONMEBOL, and other non-official websites related to football like www.zerozero.pt, www.football365.com, and www. transfermarkt.pt. These sites are the larger databases for football athletes in the world and previous studies have used some of these sites in order to collect data to analyse players' migration (see Lago-Peñas et al., 2019). For the www.zerozero.pt we used the "search" option by inserting the word "treinadores" (Portuguese for "coaches"). Next we looked for Portuguese coaches working in each confederation by looking in UEFA and Portugal. Then we filtered the information in relation to the coaches working abroad by identifying the country of the team (e.g., Angola) and finally we identified how many were working abroad between 2009 and 2013. We then used a combination of these sites to check if the number of coaches working abroad in each year matched across different sites. For example for the www.transfermarket.pt we looked in "competições" (Portuguese for "competitions" or "matches") then "treinadores no estrangeiro" (Portuguese for "coaches abroad") and compared with the data collected in www.zerozero.pt. In order to identify the networks we looked at all former foreign clubs or national teams the coach worked at (as an athlete, assistant coach or head coach) and we identified the other Portuguese coaches and athletes working in the same club or national team at the same time. This method allowed us to obtain data that was not otherwise accessible and reduced the time and costs associated with accessing primary data.

\section{Procedures}

In order to track the changes through time and the pathways and networks established by the Portuguese football coaches during this time window, we used a geographical information system (GIS). This allowed us to visualise the different patterns, and to perform spatial analyses which clarified the main moves, migratory sites or the intensity of flows.

Data analysis

The secondary data was organized within the 
QGIS project file. After assigning the data and the correspondent attributes, we were able to perform representations and later to make use of geo-processing tools. With this work, we strained to offer more levels of analysis, in a more dynamic way, moving from the more static information offered inside tables or charts. In other words, we are also pinpointing that all the different variables were assigned with information about time and space. These were important features in terms of informing our research.

\section{Results}

Patterns of coaches' migration in 2009-2013 Continental distribution

On average $35(S D=6.4)$ head coaches were found working in five of six continents and in 44 dif- ferent countries across the 2009-2013 period. From 2009 to 2013 we found the total number of coaches working abroad were, respectively: 25, 34, 41, 40, 36. The spatial distribution of Portuguese football coaches working abroad increased from 2009 with 25 coaches to 2011 with 41 coaches. We found a higher proportion of coaches in three continents: Asia $(M=$ $11.8, S D=4.1)$, Africa $(M=10.4, S D=1.7)$; and Europe $(M=9.8, S D=2.9)$. Differences were found when comparing the continent with the highest proportion of Portuguese football coaches during the time interval (see Figure 1). In 2009, Africa had the highest proportion of Portuguese football coaches. In 2010 and 2011, Asia had the highest proportion of Portuguese football coaches. In 2012, the highest proportion of Portuguese football coaches' migration was found in Europe. In 2013, Africa had again the highest proportion of Portuguese football coaches.

Table 1. Number of Portuguese football coaches present in 5 host continents

\begin{tabular}{|l|l|l|l|l|l|l|l|}
\hline Confederation & $\mathbf{2 0 0 9}$ & $\mathbf{2 0 1 0}$ & $\mathbf{2 0 1 1}$ & $\mathbf{2 0 1 2}$ & $\mathbf{2 0 1 3}$ & $\mathbf{M}$ & SD \\
\hline UEFA & 7 & 7 & 11 & 14 & 10 & 9.8 & 2.9 \\
\hline CAF & 9 & 9 & 10 & 11 & 13 & 10.4 & 1.7 \\
\hline AFC & 8 & 15 & 17 & 11 & 8 & 11.8 & 4.1 \\
\hline CONMEBOL & 1 & 1 & 2 & 2 & 2 & 1.6 & 0.5 \\
\hline CONCACAF & 1 & 2 & 1 & 2 & 3 & 1.8 & 0.8 \\
\hline M & 25 & 34 & 41 & 40 & 36 & 35.2 & 6.4 \\
\hline SD & 5.2 & 6.8 & 8.2 & 8 & 7.2 & & \\
\hline
\end{tabular}

Table 2. Number of Portuguese football coaches present in different countries

\begin{tabular}{|l|l|c|c|c|c|c|c|c|}
\hline Confederation & Federation & $\mathbf{2 0 0 9}$ & $\mathbf{2 0 1 0}$ & $\mathbf{2 0 1 1}$ & $\mathbf{2 0 1 2}$ & $\mathbf{2 0 1 3}$ & $\mathbf{M}$ & SD \\
\hline UEFA & Italy & 1 & 0 & 0 & 0 & 0 & 0.2 & 0.4 \\
\hline UEFA & Romania & 1 & 1 & 2 & 1 & 0 & 1.0 & 0.7 \\
\hline UEFA & England & 1 & 1 & 1 & 1 & 2 & 1.2 & 0.4 \\
\hline UEFA & Turkey & 1 & 0 & 1 & 1 & 0 & 0.6 & 0.5 \\
\hline UEFA & Lithuania & 1 & 1 & 0 & 0 & 0 & 0.4 & 0.5 \\
\hline UEFA & France & 1 & 0 & 0 & 0 & 0 & 0.2 & 0.4 \\
\hline UEFA & Switzerland & 1 & 1 & 1 & 1 & 0 & 0.8 & 0.4 \\
\hline UEFA & Greece & 1 & 1 & 2 & 3 & 1 & 1.6 & 0.9 \\
\hline UEFA & Spain & 0 & 2 & 1 & 2 & 0 & 1.0 & 1.0 \\
\hline UEFA & Scotland & 0 & 0 & 1 & 0 & 0 & 0.2 & 0.4 \\
\hline UEFA & Russia & 0 & 0 & 1 & 0 & 0 & 0.2 & 0.4 \\
\hline
\end{tabular}




\begin{tabular}{|c|c|c|c|c|c|c|c|c|}
\hline UEFA & Hungary & 0 & 0 & 1 & 2 & 1 & 0.8 & 0.8 \\
\hline UEFA & Cyprus & 0 & 0 & 0 & 2 & 2 & 0.8 & 1.1 \\
\hline UEFA & Serbia & 0 & 0 & 0 & 1 & 1 & 0.4 & 0.5 \\
\hline UEFA & Israel & 0 & 0 & 0 & 0 & 1 & 0.2 & 0.4 \\
\hline UEFA & Norway & 0 & 0 & 0 & 0 & 1 & 0.2 & 0.4 \\
\hline UEFA & Luxemburg & 0 & 0 & 0 & 0 & 1 & 0.2 & 0.4 \\
\hline CAF & Egypt & 0 & 0 & 1 & 0 & 0 & 0.2 & 0.4 \\
\hline CAF & Mozambique & 0 & 0 & 1 & 4 & 4 & 1.8 & 2.0 \\
\hline CAF & Burkina Faso & 1 & 1 & 1 & 0 & 0 & 0.6 & 0.5 \\
\hline CAF & Tunisia & 1 & 0 & 0 & 0 & 0 & 0.2 & 0.4 \\
\hline CAF & Cape Verde & 1 & 1 & 0 & 0 & 0 & 0.4 & 0.5 \\
\hline CAF & Angola & 4 & 7 & 7 & 4 & 7 & 5.8 & 1.6 \\
\hline CAF & Tanzania & 1 & 0 & 0 & 0 & 0 & 0.2 & 0.4 \\
\hline CAF & Morocco & 1 & 0 & 0 & 0 & 0 & 0.2 & 0.4 \\
\hline CAF & Guinea Bissau & 0 & 0 & 0 & 2 & 1 & 0.6 & 0.9 \\
\hline CAF & Gabon & 0 & 0 & 0 & 1 & 1 & 0.4 & 0.5 \\
\hline AFC & Saudi Arabia & 4 & 4 & 3 & 2 & 1 & 2.8 & 1.3 \\
\hline AFC & Syria & 1 & 0 & 0 & 0 & 0 & 0.2 & 0.4 \\
\hline AFC & UAE & 1 & 2 & 1 & 0 & 1 & 1.0 & 0.7 \\
\hline AFC & Bahrain & 1 & 1 & 0 & 0 & 0 & 0.4 & 0.5 \\
\hline AFC & Vietnam & 1 & 2 & 2 & 0 & 0 & 1.0 & 1.0 \\
\hline AFC & Kuwait & 0 & 1 & 2 & 1 & 1 & 1.0 & 0.7 \\
\hline AFC & Iran & 0 & 3 & 3 & 5 & 2 & 2.6 & 1.8 \\
\hline AFC & South Korea & 0 & 1 & 0 & 0 & 0 & 0.2 & 0.4 \\
\hline AFC & Oman & 0 & 1 & 2 & 0 & 0 & 0.6 & 0.9 \\
\hline AFC & China & 0 & 0 & 3 & 2 & 1 & 1.2 & 1.3 \\
\hline AFC & Macau & 0 & 0 & 1 & 1 & 1 & 0.6 & 0.5 \\
\hline AFC & Malaysia & 0 & 0 & 0 & 0 & 1 & 0.2 & 0.4 \\
\hline CONMEBOL & Brazil & 1 & 1 & 2 & 2 & 2 & 1.6 & 0.5 \\
\hline CONCACAF & USA & 1 & 1 & 1 & 1 & 1 & 1.0 & 0.0 \\
\hline CONCACAF & Guatemala & 0 & 1 & 0 & 0 & 0 & 0.2 & 0.4 \\
\hline CONCACAF & Mexico & 0 & 0 & 0 & 1 & 1 & 0.4 & 0.5 \\
\hline \multirow[t]{3}{*}{ CONCACAF } & Costa Rica & 0 & 0 & 0 & 0 & 1 & 0.2 & 0.4 \\
\hline & M & 25 & 34 & 41 & 40 & 36 & 35.2 & 6.4 \\
\hline & SD & 5.2 & 6.8 & 8.2 & 8 & 7.2 & & \\
\hline
\end{tabular}


Figure 1. Number of Portuguese football coaches present in 5 host continents. Within each graph each bar represents a year of data collection from 2009 in white to 2013 in black. Note that migration was primarily to Europe, Africa and Asia (see table 1 for exact numbers).

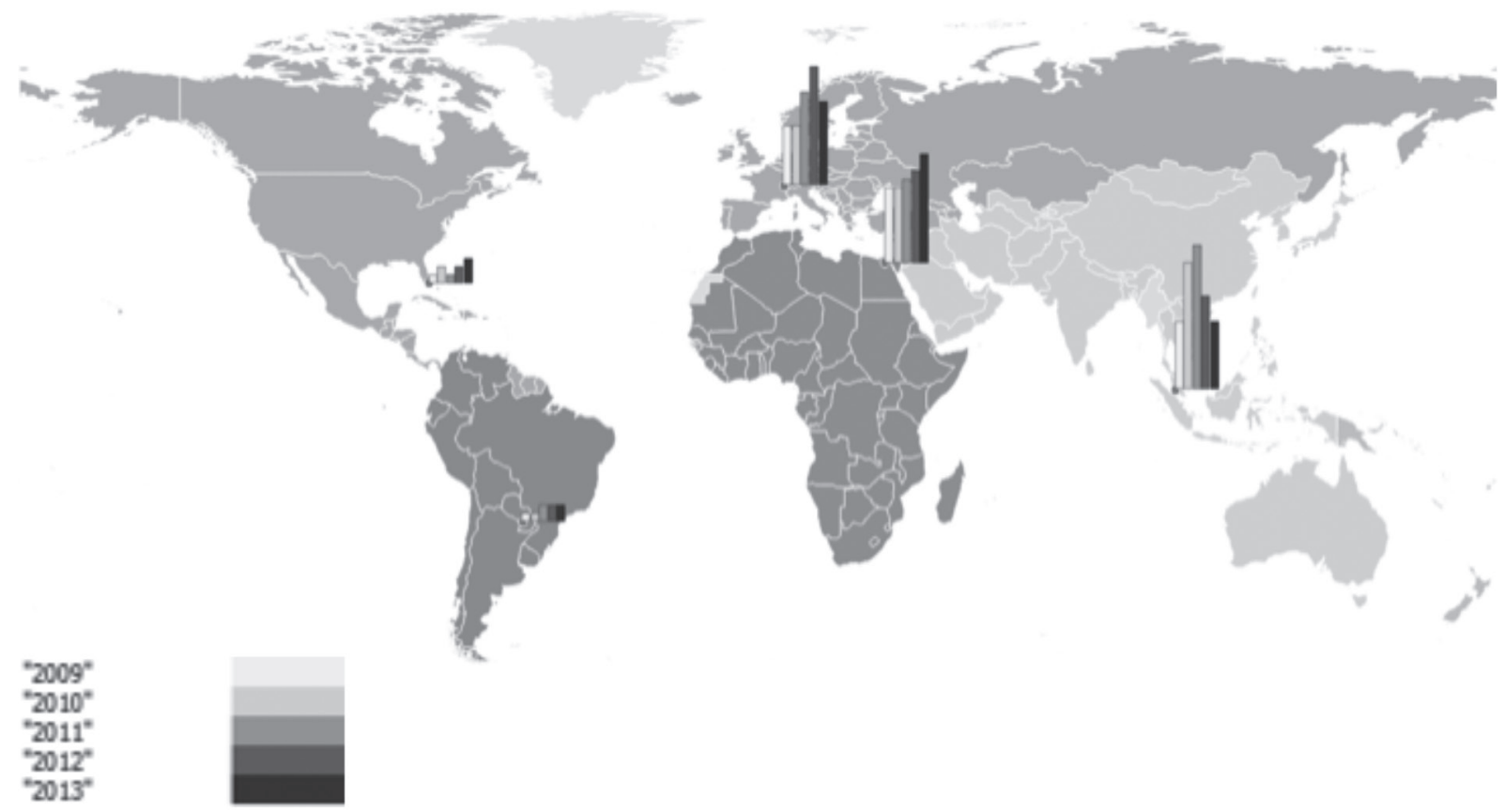

Figure 2. Number of Portuguese football coaches present in different countries. Within each graph bars represent a year of data collection from 2009 in white to 2013 in black. Note large numbers of coaches in Angola, Saudi Arabia, Mozambique and Iran (see table 2 for exact numbers).

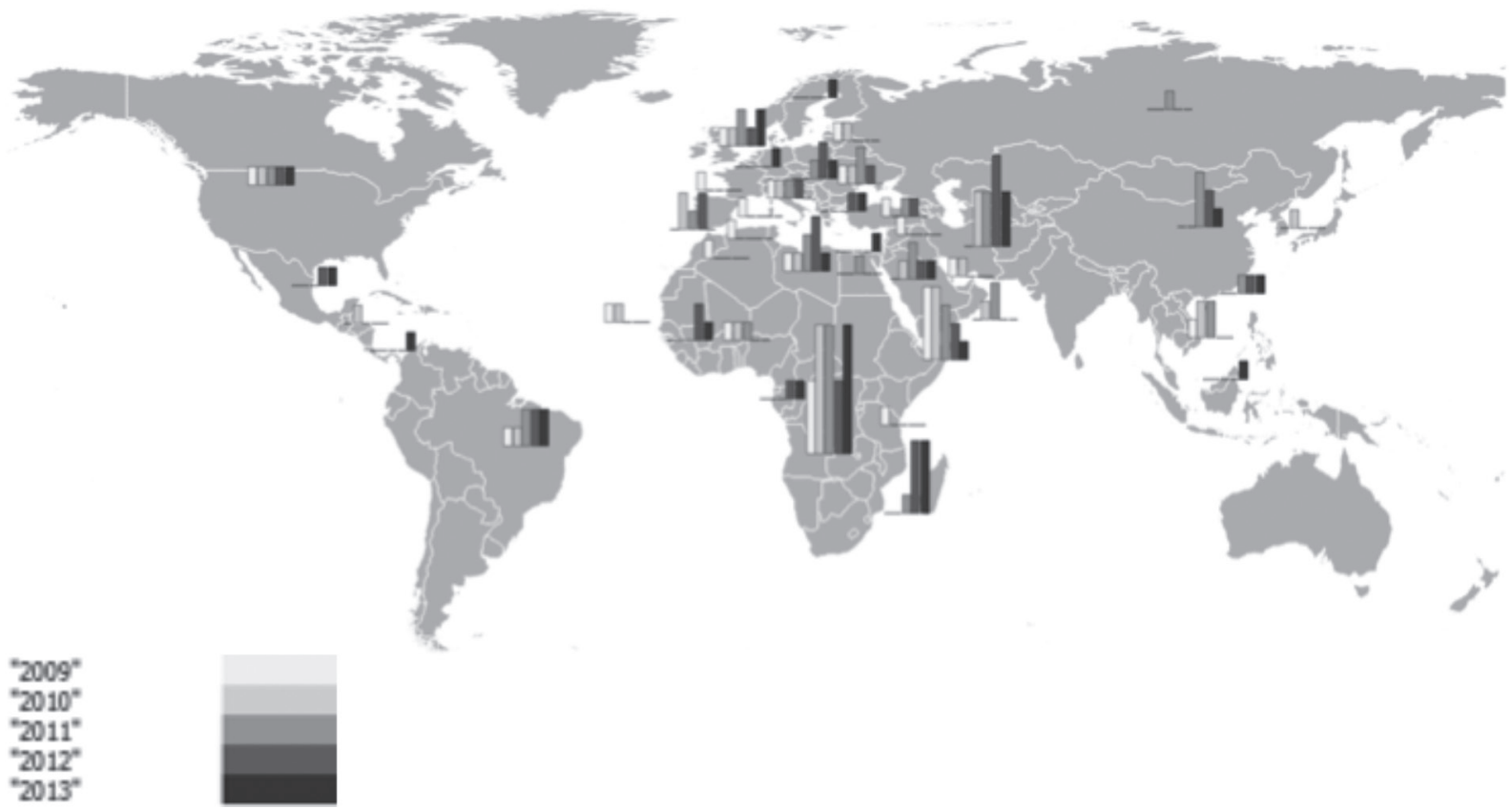




\section{Country distribution}

Angola was the country which hosted the highest proportion of Portuguese football coaches in all years (see Figure 2). During the time interval we found differences when comparing the proportion of coaches in different countries. Within Asia the countries which appeared as preferred hosts for Portuguese football coaches were: Saudi Arabia (2009 and 2010), China (2011), Iran (2011, 2012, 2013). Within Africa some countries also appeared as preferred hosts: Angola (2009 to 2013), Mozambique (2012). Within Europe there was a larger spread of preferred host countries: Italy, Romania, England, Turkey, Lithuania, France, Switzerland and Greece (2009), Spain (2010), Greece (2010, 2012), England and Cyprus (2013). Within the two continents hosting the least Portuguese football coaches, the preferred host countries were Brazil (2009 to 2013), Guatemala (2010), USA (2011, 2013), Mexico (2012, 2013), and Costa Rica (2013).

\section{In-depth analysis of migrant coaches in 2013}

\section{Demographic patterns}

An in-depth analysis of migrant coaches working abroad in 2013 was made in regards to the demographic aspects: age, previous experiences abroad as head coaches, assistant coaches and/or athletes, return migration (i.e., coaches who returned to their country of origin after having lived abroad). In regards to age we found that Portuguese football coaches were on average 48.5 years old $(S D=9.4)$, ranging from 27 to 67 years old. Among all continents, the older coaches were in Af- rica $(M=54.6, S D=5.9, n=13)$ and the younger coaches were in Europe $(M=41.6, S D=4.6, n=10)$.

In regards to previous emigration experiences, the majority of head coaches who were abroad in 2013 had worked in a foreign country previously as head coaches $(n=32)$, and/or assistant coaches ( $n=8)$ and/ or players ( $n=7$ ). Most of those migrations had been between Africa and Asia, and inside Europe (see Table 1). Among coaches who were in Africa $(n=13)$ or Asia $(n=9)$, we found the least previous experiences abroad ( 2 had been assistant coaches and 1 had been a player abroad). Among coaches who were in Europe they had worked mainly in the continent (only 1 had also worked in Africa) as head coaches ( $n=10)$, and/or assistant coaches $(n=3)$, and/or players $(n=4)$.

In regard to return migration we have measured the number of times that a coach returned to his/her country of origin after have moved abroad. We have identified 14 coaches who had returned to Portugal during their careers (overall number of return migrations: $M=0.6 ; S D=1.0$ ). Coaches who were in North and Central America return more times to work in Portugal $(M=1.7 ; S D=2.1)$ and the coaches who were in South America never returned to Portugal. The coach with the most return migrations $(n=4)$ was in Costa Rica. In Asia the three coaches with most return migrations ( $n=2$ ) were in China, UAE and Malaysia. In Europe two coaches who worked in Greece and England had the most return migrations $(n=2)$. In Africa two coaches who worked in Angola had the highest number of return migrations $(n=2)$. The return migrations of only $38 \%$ of coaches may suggest a difficulty for them to continue their career in Portugal.

Table 3. Number of coaches with experiences abroad per continent and role

\begin{tabular}{|c|c|c|c|c|c|c|}
\hline \multirow{2}{*}{$\begin{array}{c}\begin{array}{c}\text { Coaches } \\
\mathbf{N}=\mathbf{3 7}\end{array} \\
\begin{array}{c}\text { Europe } \\
(n=10)\end{array} \\
\end{array}$} & \multicolumn{2}{|c|}{$\begin{array}{c}\text { Number and continent } \\
\text { as head coach }\end{array}$} & \multicolumn{2}{|c|}{$\begin{array}{l}\text { Number and continent } \\
\text { as assistant coach }\end{array}$} & \multicolumn{2}{|c|}{$\begin{array}{c}\text { Number and continent } \\
\text { as player }\end{array}$} \\
\hline & $\begin{array}{c}10 \\
1\end{array}$ & $\begin{array}{l}\text { Europe } \\
\text { Africa }\end{array}$ & 3 & Europe & 4 & Europe \\
\hline $\begin{array}{l}\text { Africa } \\
(n=13)\end{array}$ & $\begin{array}{l}13 \\
2 \\
2\end{array}$ & $\begin{array}{c}\text { Africa } \\
\text { Asia } \\
\text { Europe }\end{array}$ & 0 & - & 1 & Europe \\
\hline $\begin{array}{l}\text { Asia } \\
(n=9)\end{array}$ & $\begin{array}{l}9 \\
5 \\
2 \\
2\end{array}$ & $\begin{array}{c}\text { Asia } \\
\text { Africa } \\
\text { North and Central } \\
\text { America } \\
\text { Europe } \\
\end{array}$ & $\begin{array}{l}2 \\
1 \\
1\end{array}$ & $\begin{array}{c}\text { Asia } \\
\text { Africa } \\
\text { Europe }\end{array}$ & $\begin{array}{l}1 \\
1\end{array}$ & $\begin{array}{c}\text { Africa } \\
\text { North and Central } \\
\text { America }\end{array}$ \\
\hline $\begin{array}{l}\text { North and Central } \\
\text { America } \\
(n=3)\end{array}$ & $\begin{array}{l}3 \\
1\end{array}$ & $\begin{array}{c}\text { North and Central } \\
\text { America } \\
\text { Africa }\end{array}$ & $\begin{array}{l}1 \\
1\end{array}$ & $\begin{array}{l}\text { Asia } \\
\text { Europe }\end{array}$ & 0 & - \\
\hline $\begin{array}{l}\text { South America } \\
\qquad(\mathrm{n}=2)\end{array}$ & 2 & South America & 0 & - & 0 & - \\
\hline
\end{tabular}




\section{Networks}

A network refers to a group of coaches or athletes, with the same nationality who have worked abroad in the same club or national team. All Portuguese head coaches working abroad in 2013 had previously worked with at least one Portuguese coach or athlete (See table 2). These networks were more prominent in Europe $(M=4.7 ; S D=4.4)$. There were more network relations between head coaches and assistant coaches $(M=2.1 ; S D=1.7)$, and between head coaches and players $(M=2.6 ; S D=3.4)$. Interestingly, in Asia we also found a large number of network relations between head coaches and other coaches and players $(M=3.0 ; S D=1.5)$. The highest number of network relations was found for coaches working in Spain and Greece $(n=12)$. Networks of head coaches with other coaches was highest for those working in Iran, Greece and Gabon $(n=5)$ and the highest social relations with athletes were found for coaches in Spain $(n=8)$.

Table 4. Average size of networks of coaches who were abroad in 2013. These networks were gathered from tracing the careers of head coaches since their first migration and include both players and other coaches. Note that coaches in Europe and Asia had large networks in contrast with coaches in South America. The number of individuals in the network is given below (standard deviations in parenthesis).

\begin{tabular}{|c|c|c|c|}
\hline \multirow{2}{*}{ Continents } & \multicolumn{3}{|c|}{ Number of individuals in the Networks (SD) } \\
\cline { 2 - 4 } & $\begin{array}{c}\text { Assistant and } \\
\text { head coaches }\end{array}$ & Players & Total networks \\
\hline Europe & $2.1(1.7)$ & $2.6(3.4)$ & $4.7(4.4)$ \\
\hline Africa & $1.8(2.2)$ & $0.5(0.6)$ & $2.6(2.3)$ \\
\hline Asia & $2.0(1.8)$ & $1.3(1.1)$ & $3.0(1.5)$ \\
\hline North and Central America & $2.0(1.7)$ & $0.7(2.7)$ & $2.7(1.5)$ \\
\hline South America & $0.0(0.0)$ & $1.0(0.0)$ & $1.0(0.0)$ \\
\hline
\end{tabular}

\section{Discussion}

Our results show that the destination pattern of Portuguese football coaches involves both peripheral and central areas of football prestige. This hybridization of Portuguese migration corroborates previous studies with players, which located Portugal in the semi-peripheral zone of world football prestige (Nolasco, 2010, 2012). Transcontinental peripheral migration was found specifically to Angola, Saudi Arabia, China and Iran which are African and Asian which are countries where football prestige is small. Similarly, intra-continental migrations were found to peripheral zones inside Europe to Romania, Lithuania, Turkey, Switzerland, Greece and Cyprus. These results complement those from Magee and Sugden (2002) who showed that players migrated from the peripheral zone of Africa to the core zone of Europe. InterestingIy, our study shows that coaches migrate in the opposite direction to players, but in the same direction as the worldwide diffusion of football which is from the core to the periphery (Magee \& Sugden, 2002, Taylor, 2010). Within the core of Europe, some coaches were working in the most prestigious leagues in the world, such as England, Spain, Italy and France. This is the case of coaches such as Jose Mourinho who have extensive experience working in the best European leagues. This is also the case for players like Ronaldo who migrated to England and Spain. It is likely that the migration of Portuguese coaches to the European core lends prestige to Portuguese football, as has been argued for Portuguese players (Besson, Poli \& Ravenel, 2013).

The pattern of destination countries suggests that the migration of coaches results from an overlap of economic, historical and cultural factors. This is in accordance with previous studies analysing the patterns of the migrant football players present in the World Cup 1998 (Maguire et al., 2002). They found that players often migrated from ex-colonies and from underdeveloped economies. In the case of Portuguese coaches it is important to recall that 2009-2013 were 
years of financial crisis with high rates of unemployment. This may partly explain why coaches migrated to countries with emergent economies in Africa and Asia where coaches were able to manage their careers abroad. In accordance to previous studies, football coaches are motivated to migrate because of their career ambitions. Therefore they may have moved to Angola and Saudi Arabia, which are less prestigious leagues, to revive or prolong their football coaches' career (Smith, 2014). Historical relations were also shown empirically with Angola, which was a Portuguese colony, appearing as the main destination country. However, it is noteworthy that Angola is an emergent economy unlike other Portuguese ex-colonies and its financial attractiveness may be an overlapping factor in making it a preferred destination. Other cultural factors such as language have been shown to play a role in players' migration from Africa to Portugal (Darby, 2007) but a recent study suggests this may not be a primary factor for coaches migrating from Portugal to Africa (Borges et al., 2015).

The growth in the number of coaches abroad between 2009 and 2013 suggests that the economic crisis had an impact on Portuguese coaches' migration. This is in line with the increased emigration that occurred in Portugal from 2009 to 2011 (16.899 individuals to 43.998 individuals). At the same point in time, the unemployment rate had increased from $9.4 \%$ in 2009 to $12.7 \%$ in 2011 . This suggests that coaches may have faced challenges in terms of job opportunities in Portugal and may also have had difficulties to negotiate better contracts. Given there is a limited number of opportunities to work as a professional football coach in the $1^{\text {st }}$ national leagues, this could have impacted on coaches decisions to move abroad. Interestingly, the larger number of coaches' migration were to leagues outside the European continent (which was facing an economic crisis at the time) to other countries considered to be emergent economies. These may have been attractive because at that point in time they would have been able to offer better contracts to the coaches.

Another interesting result was the network relations found during the careers of Portuguese coaches. Coaches who were working abroad in 2013 had been circulating between countries, and had been working with other Portuguese coaches and players since leaving Portugal. In agreement with previous studies, we found that these networks were important in the recruitment of coaching staff (Taylor, 2010) and players (Agergaard \& Botelho, 2011; Elliott \& Maguire, 2011). Specifically worth noting are the networks of coaches migrating to Asia, with the largest networks, and to Africa, with the smallest networks.
The size of these networks can distinguish these two transcontinental movements and may be caused by economic or cultural trends. For instance coaches are better able to migrate alone to countries with more cultural similarities, such as the language in African ex-colonies. On the other hand, the networks may have greater relevance for coaches who migrate to very different cultures, such as the language, food and religion in Asian countries. Also, the economic prestige of Asian countries such as Saudi Arabia allows all the coaching staff to achieve lucrative deals. Taken together, cultural and financial factors may be at the root of the large networks seen surrounding head coaches in Asia.

Last but not least, previously migration experiences appear to make Portuguese coaches better able to manage their careers in the football global market. We found that coaches who had previous migration experiences in Europe, either as players or assistant coaches circulate inside this more prestigious zone. In agreement with Smith (2014) our data confirms that coaches with circulatory careers within Europe gain prestige as coach which enables them to continue in the highest-level leagues in Europe. A prominent illustration is Jose Mourinho who was an assistant coach in FC Barcelona and, after his success as head coach in FC Porto, was able to secure head coach jobs in Chelsea FC, FC Internazionale Milano, Real Madrid CF. On the other hand, coaches who had previous migration experiences as football players in the highest leagues are still circulating in Europe but in the peripheral zone. This is the case of Paulo Sousa who gained visibility in the football market as a player at Milan and Dortmund, and who is now coaching in peripheral European leagues (Netherlands and Cyprus). In this sense we add to Carter (2011) who argued that visibility is essential to coaches' career in the global market because we qualify the type of visibility that lends prestige to migrant coaches. Visibility as assistant coach seems to be more valuable than visibility as former player. For instance, Villas-Boas, who never had a prominent career as player, gained visibility in the football global market through his experiences abroad. As an assistant coach of Jose Mourinho at Chelsea FC and FC Internazionale Milano, he was recruited as head coach in Coimbra and FC Porto and later in Chelsea FC. On the other hand, we found that coaches who did not have previous experiences in Europe are mainly working in Africa, Asia, and North and Center America. It is possible that these coaches migrated to lower-level leagues to revive and prolong their careers. For instance our results show that they these are the oldest Portuguese football coaches working 
abroad and those who have the largest number of return migrations.

This study has limitations that are worth considering and points directions for future research. First, restricting the analysis to Portuguese football coaches limits the generalization to other nationalities and sports. Future research should consider different universes of coaches differentiated by their nationality or sport. Second, the patterns of migration should consider more demographic aspects such as the academic and coaching qualifications. It is important to analyze how coaches are distributed according to their qualifications and whether their coach education programs prepare them for the challenges of sport migration. For instance, it would be important to raise awareness of trainee coaches for the possible importance of migration in their careers and in educating them for the special requirements in the training of different countries and cultures. Beyond zones of football prestige, it is important to identify the developmental level of football in different championships and what strategies can be devised to succeed under different constraints. This includes the use of informal networks of coaches and players who can share knowledge and advise the recruitment of migrant coaches.

\section{References}

Agergaard, Sine, and Botelho Vera. 2011. "Female football migration. Motivational factors for early migratory process". In Sport and migration: Border, boundaries and crossings, edited by J. Maguire and M. Falcous, 157-172. London: Routledge.

Andreff, Wladimir. 2011. "Why tax international athlete migration? The 'Coubertin' tax in a context of financial crisis". In Sport and migration: Border, boundaries and crossings, edited by J. Maguire and M. Falcous, 31-45. London: Routledge.

Armstrong, Gary, and Giulianotti Richard. 2004. Football in Africa: Conflict, Conciliation and Community. Basingstoke and New York: Palgrave Macmillan,

Bale, John. 1989. Sports Geography. London: E. \& F.N. Spon,

Bale, John, and Maguire Joseph. 1994. The global sports arena: athletic talent migration in an interdependent world. London: CASS,

Bale, John, and Dejonghe Trudo. 2008. "Sports Geography: an overview". Belgeo 2. Retrieved from http://belgeo.revues.org/10253

Besson, Roger, Poli Raffaele, and Ravenel Loic. 2013. CIES Football Obsevatory Demographic Study 2013. Neuchâtel: Centre International d'Etude du Sport.
Borges, Mario, Rosado Antonio, de Oliveira Rita and Freitas Freitas. 2015. "Coaches' migration: A qualitative analysis of recruitment, motivations and experiences". Leisure Studies, 34 (5): 588-602.

Carter, Thomas. 2004. The migration of sporting labour into Ireland. In Sport and the Irish: Histories, identities, issue, edited by A. Bairner, 191-205. Dublin: University College Dublin Press.

Carter, Thomas. 2011. In Foreign Fields. The Politics and Experiences of Transnational Sport Migration. London, UK: Pluto Press.

Darby, Paul. 2007. "African Football Labour Migration to Portugal: Colonial and Neo-Colonial Resource". Soccer in Society, 8 (4): 495-509.

Eurostat 2014. "Unemployment statistics". October.http://epp.eurostat.ec.europa.eu/

statistics_explained/index.php/Unemployment_ statistics

Elliot, Richard, and Maguire Joseph. 2011. "'Netgains'. Informal recruiting, Canadian players and British professional ice hockey". In Sport and migration: border, boundaries and crossings, edited by J. Maguire and M. Falcous, 103-111. London: Routledge.

Lanfranchi, Pierre, and Taylor Matthew. 2001. Moving with the ball: The migration of professional footballers. Oxford: Berg.

Lima, Maria. 2010. Government announces new measures to tackle unemployment. Eurofound. March15. http://eurofound.europa.eu/observatories/eurwork/articles/other/government-announces-new-measures-to-tackle-unemployment.

Magee, Jonathan, and Sugden John. 2002. "The world at their feet': Professional football and international labour migration". Journal of Sport and Social Issues, 26: 421-437.

Maguire, Joseph. 1999. Global sport: Identities, societies, civilisations. Cambridge: Polity.

Nolasco, Carlos. 2009. "Moving Behind the Ball: Migratory Flows of Portuguese Football". World Congress of the Sociology of Sport, Utrecht University: Netherlands.

Poli, Raffaele. 2008. "Les footballeurs maghrébins en Suisse (1962-2008)". Migrance, 29: 74-81.

Poli, Raffaele. 2010. "Understanding globalization through football: the new international division of labour, migratory channels and transnational trade circuits". International Review for the Sociology of Sport, 45 (4): 491-506.

Poli, Raffaele, and Besson Roger 2011. "From the South to Europe. A comparative analyses of African and Latin football migration". In Sport and migration: Border, boundaries and crossings, edited by J. Maguire and M. Falcous, 15-30. London: Routledge. 
Poli, Raffaele, Besson Roger, and Ravenel Loic. 2013. CIES Football Observatory Annual Review 2013. Neuchâtel: Centre International d’Etude du sport.

Smith, Graham. 2016. Migratory career contingencies of elite level soccer coaching talent. Soccer \& Society, 17 (4): 407-432.

Sugden, John, and Tomlinson Alan. 2002. Power games. A critical sociology of sport. London: Routledge.

Taylor, Matthew. 2010. "Football's Engineers? British Football Coaches, Migration and Intercultural Transfer, c.1910-c.1950s". Sport in History, 30 (1): 138163.

Wallerstein, Immanuel. 1974. The modern world system. New York: New York Academy Press. 